\title{
EKSPRESI IDIOMATIK DALAM LIRIK “NINE TRACK MIND” CHARLIE PUTH ALBUM 2016
}

\author{
Varia Virdania Virdaus \\ Email: varia.virdaus@narotama.ac.id
}

\begin{abstract}
Abstrak: Bahasa digunakan sebagai alat komunikasi yang mengizinkan setiap orang untuk berkomunikasi dengan orang disekitarnya. Para pelajar bahasa sadar bahwa untuk memahami percakapan informal yang biasa digunakan oleh native speaker, mereka membutuhkan informasi dan petunjuk untuk membantu mereka dalam menggunakan ungkapan yang cocok dalam situasi tertentu. Musik adalah salah satu media yang bisa dgunakan untuk memperkenalkan dan meninjau kembali kosa kata mereka, termasuk ungkapan idiom. Tujuan penelitian ini adalah untuk menemukan dan menjelaskan arti ungkapan-ungkapan idiom yang ada pada lirik lagu Charlie Puth dalam album Nine Track Mind tahun 2016. Jenis data yang digunakan dalam penelitian ini adalah metode kuantitatif deskriptif karena untuk menjelasakan tentang mengumpulkan, menganalisis, menggambarkan, mengidentifikasi jenis idiom dalam album Charlie Puth, dan untuk menghitung jumlah idiom.
\end{abstract}

Kata Kunci: Idiom, Lirik, Charlie Puth, Nine Track Mind Album

\begin{abstract}
Language is used for communication which allows people say things to each other and express their communicative needs. Language learners are aware that to understand the informal form of conversation used by native speakers of English, they need information and guidance to assist them in using the appropriate idioms in a given situation. English songs are one of the media of introducing and reviewing vocabulary, including idiomatic expressions. The purpose of this study is to find out and explain the meaning of idiomatic expressions in Charlie Puth's song lyrics in album Nine Track Mind 2016. The type of data used in this study was a descriptive quantitative method because to the point out about collects, analysis, describes, identifies the idiomatic expression in Charlie Puth's album, and to count of idiomatic expression.
\end{abstract}

Key Words: Idiom, Lyric, Charlie Puth, Nine Track Mind Album 


\section{PENDAHULUAN}

Bahasa adalah alat komunikasi untuk menyampaikan berbagai macam informasi, ekspresi, dan perasaan satu sama lain. Bahasa dapat diekspresikan dalam bentuk tertulis. Dengan cara sastra, manusia dapat mengekspresikan perasaan mereka seperti menulis karya sastra seperti puisi, novel, dan bahkan lirik lagu. Artinya Bahasa adalah alat untuk menyampaikan ide, pemikiran, pendapat dan perasaan. Menurut (Brown, 2002) bahasa adalah suatu sistem simbol-simbol vokal, tulisan, atau isyarat konvensional yang sewenang-wenang yang memungkinkan para anggota komunitas tertentu untuk berkomunikasi secara cerdas satu sama lain. Salah satu bahasa yang paling penting untuk dipelajari adalah bahasa Inggris. Ini adalah bahasa yang penting saat ini karena menjadi bahasa internasional. Orang bisa hidup karena bahasa, tanpa bahasa mereka tidak bisa berinteraksi dengan orang lain. Selain itu, bahasa ada di mana manusia berkumpul dan mereka perlu melakukan fungsi kehidupan sosial mereka terutama dalam musik. Banyak orang menyukai lagu, tetapi mereka sering salah paham tentang arti lirik itu sendiri.

Lagu adalah komposisi nada atau bunyi seni dalam urutan, kombinasi, dan hubungan temporal, biasanya diiringi oleh alat musik untuk menghasilkan komposisi musik yang memiliki kesatuan dan kontinuitas (mengandung ritme). Karakteristik lagu-lagu tersebut adalah puisi pendek, formal dalam meter dan sajak, dan lebih mementingkan perasaan pribadi daripada cerita atau ide. Lagu lirik tidak seperti kata-kata yang digunakan secara langsung. Terkadang, itu disampaikan dengan bahasa kiasan seperti puisi. Lirik puisi harus terdiri dari kiasan dan ungkapan. Tanpa mengetahui idiom pendengar tidak akan tahu makna yang disampaikan oleh pembicara.

Istilah idiom biasanya digunakan dalam bahasa Inggris, baik dalam tulisan maupun percakapan. Idiom sering ditemukan di koran, majalah, artikel, puisi, novel, dan lirik. Secara umum, lirik adalah puisi yang dinyanyikan dan diiringi oleh musik, yang sering mengungkapkan ide dan perasaan penulis. Menurut Chaer (2009: 74) idiom adalah satuan bahasa (bisa berupa kata, frasa, atau kalimat) yang 
maknanya tidak bisa "diramalkan" dari makna leksikal dan makna gramatikal. Terkadang, idiom juga tidak dapat diterjemahkan secara harfiah dan harus dipahami atau diingat.

Belajar Bahasa Inggris sebagai Bahasa Asing tidak semudah memperoleh bahasa pertama. Pelajar harus menyadari dengan sejumlah unit bahasa yang berbeda termasuk tata bahasa, pengucapan, pembentukan kata dan sejenisnya. Masih rumit bagi pelajar untuk beradaptasi dengan unit bahasa baru yang berbeda dari mereka sendiri. Karena banyak alasan, idiom sulit dipelajari dan diajarkan. Seperti yang dinyatakan oleh McPartland (1981), idiom tidak literal: idiom tidak berarti apa yang mereka katakan dan yang paling sulit adalah mereka yang tidak memiliki rekan dan yang artinya tidak dapat diturunkan dari makna gabungan dari konstituen mereka. Alasan lainnya adalah karena idiom umum dalam kehidupan sehari-hari Amerika dan menyediakan sumber budaya Amerika yang kaya (Cooper, 1999).

Palmer (1976: 99) telah menyatakan bahwa ada tiga jenis idiom; kata kerja phrasal, kata kerja preposisi dan idiom parsial. Kata kerja frase adalah jenis idiom yang sangat umum dalam bahasa Inggris. Apa yang biasanya disebut kata kerja phrasal adalah kombinasi dari kombinasi kata kerja dan kata keterangan (Palmer, 1976: 99). Arti dari kombinasi ini tidak dapat diprediksi dari kata kerja dan kata keterangan individu. Kata kerja preposisional adalah urutan kata kerja dan kata depan atau kata kerja, kata kerja dan kata depan. Itu bisa dilihat pada contohcontoh yang diberikan seperti merawat, mencari, bertahan, dan menyingkirkan. Ekspresi yang menunggu adalah milik kata kerja preposisional karena merupakan urutan kata kerja ditambah preposisi. Tipe idiom lain ada dalam apa yang disebut idiom parsial. Di sinilah salah satu kata memiliki arti yang biasa dan yang lain memiliki makna yang khas untuk urutan tertentu.

Berdasarkan informasi latar belakang di atas, penelitian ini akan mencari tahu jenis dan makna idiom yang digunakan dalam album lirik Charlie Puth, Nine Track Mind 2006. Dia adalah penyanyi, penulis lagu, dan produser rekaman Amerika. One Call Away adalah album debut lagu Nine Track Mind. Album ini dirilis pada 20 Agustus 2015, oleh Atlantic Records sebagai single kedua dari 
album, setelah lead single "Marvin Gaye". Di Amerika Serikat, "One Call Away" debut di nomor 89, pada minggu yang berakhir 19 Desember 2015. Di Inggris, lagu debut di nomor 73, pada minggu yang berakhir 3 Desember 2015. Lagu ini disertifikasi ganda Platinum oleh RIAA (Asosiasi Industri Rekaman Amerika) pada 28 Juli 2016. Lagu ini telah terjual 1,575.000 kopi di dalam negeri. Singkatnya peneliti tertarik untuk menulis makalah ini berjudul "Ekspresi Idiomatik dalam Lirik Charlie Puth" Nine Track Mind "Album 2016."

\section{LANDASAN TEORI}

Penggunaan idiom selalu diterjemahkan menggunakan ekspresi idiomatik yang setara dalam bahasa target. Ungkapan idiomatik tidak selalu gramatikal, tetapi dibentuk, diterima dan digunakan oleh penutur asli bahasa dengan struktur dan makna yang tetap. Dalam hal ini, ekspresi idiomatik telah lama memainkan peran penting dalam bahasa Inggris.

Mantyla (2004) telah menyatakan bahwa idiom adalah ungkapan yang mengandung lebih dari satu kata, dan yang artinya berbeda dari jumlah makna harfiah dari komponen-komponennya.

Dengan kata lain, Martin Davies (1983) mendefinisikan idiom adalah ungkapan yang tidak dapat diterjemahkan dengan benar berdasarkan terjemahan dari kata-kata dan cara-cara penggabungan yang secara sintaksis dibedakan.

Dixson (1951) telah menyatakan bahwa idiom adalah ungkapan yang memiliki makna berbeda dengan bagian-bagian komponennya. Idiom sebenarnya berasal dari kata Yunani "idiomatikos" yang berarti "pribadi" atau "aneh".

Hurford (2007), ekspresi idiomatik (idiom) adalah frase multi-kata yang menggabungkan indera literal dari kata-kata individu dalam setiap frase. Di sisi lain, ungkapan idiomatik adalah ungkapan yang maknanya tidak sesuai dengan prinsip komposisionalitas, dan tidak terkait dengan makna bagian-bagiannya. Tetapi, makna yang dimaksudkan biasanya tergantung pada konteks di mana ungkapan itu digunakan. 
Idiom telah dikategorikan oleh banyak pakar dengan kelas yang berbeda. Hockett (1982) telah mengategorikan idiom menjadi enam tipe 1). Pengganti, jenis idiom ini terdiri dari kata ganti dan angka pribadi seperti orang pribadi (dia, dia, itu, dan mereka), yang demonstratif (ini, ini, itu, iklankan itu), dan kata kerja "lakukan". 2). Nama yang tepat, biasanya merujuk pada nama orang, tempat, binatang, roh, dan kendaraan yang menciptakan idiom baru. 3). Singkatan, penggunaan bagian untuk keseluruhan misalnya telepon yang merupakan bagian dari kata telepon, UNESCO yang merupakan singkatan dari Organisasi Pendidikan, Ilmu Pengetahuan dan Kebudayaan PBB. 4). Kata majemuk frase bahasa Inggris, artinya kata benda, kata sifat atau kata kerja yang dibuat dari dua atau lebih kata-kata sederhana dan dikaitkan dengan tanda hubung (-) misalnya: pacar yang berpakaian bagus, terkenal, pacar. 5). Figur of speech, makna katakata memiliki makna "dalam", yang berbeda dari makna "permukaan", klasifikasi untuk kiasan adalah hiperbola, litotes, oxymoron, dan ironi. 6). Gaul, itu dapat didefinisikan sebagai penggunaan kata-kata informal.

Lim (2004) telah mengusulkan enam jenis idiom, yaitu: 1). Verba phrasal. Ini adalah frasa yang mengandung kata kerja dan unsur-unsur lain seperti kata keterangan atau preposisi dan makna itu sendiri tidak dapat diturunkan dari makna literal bagiannya (makna asli unsur-unsur), tetapi artinya menarik kembali suatu pernyataan. Phrasal Verbs sebagian besar digunakan dalam formal dan informal; bahasa lisan dan tulisan. Contoh-contoh kata kerja phrasal dapat ditemukan dalam panggilan, tunda, hilangkan. 2). Frasa preposisi selalu diikuti oleh kata benda (atau kata ganti). Mereka adalah kata-kata penghubung yang menunjukkan hubungan antara kata benda yang mengikuti mereka dan unsur-unsur kalimat dasar: subjek, kata kerja, objek, atau pelengkap, biasanya menunjukkan hubungan seperti posisi, tempat, arah, waktu, dan sebagainya antara objek mereka dan lainnya. bagian dari kalimat. Contoh-contoh frasa preposisi sebagai idiom adalah: Dalam kabut, dari tangan ke mulut, dari waktu ke waktu. 3). Idiom dengan kata kerja sebagai kata kunci. Tipe idiom ini menggunakan kata kerja untuk menekankan idiom. Kata kerja adalah kata atau frasa yang menggambarkan tindakan, kondisi, atau pengalaman. Sebagai contoh: berguna, berjuang melawan, 
meninggalkan banyak yang diinginkan. 4). Idiom dengan kata benda sebagai kata kunci. Jenis idiom ini menggunakan kata benda sebagai kata kunci. Kata benda adalah kata yang merujuk pada seseorang, tempat, benda, peristiwa, substansi, atau kualitas. Contoh idiom ini dapat ditemukan dalam penyamaran berkah dan permainan anak 5). Idiom dengan kata sifat sebagai kata kunci. Tipe idiom ini menggunakan kata sifat untuk menekankan idiom itu sendiri. Kata sifat adalah kata yang menggambarkan kata benda atau kata ganti. Sebagai contoh: kenyamanan dingin, angan-angan, rencana berlayar; sopan, menuju kosong. 6). Pasangan idiomatik. Itu adalah pasangan idiomatis adalah idiom yang dibentuk oleh dua kata yang berisi kata sifat, kata benda, dan kata keterangan yang disatukan bersama untuk membentuk kalimat idiom. Sebagai contoh: aman dan sehat, pegal-pegal, tenggelam atau berenang.

Makkai (1972) klasifikasi idiom leksemik, yang dibagi lagi menjadi enam subkelas: idiom kata kerja phrasal, idiom turnamen, binomial ireversibel, idiom senyawa ungkapan, menggabungkan idiom kata kerja dan idiom semu.

1). Idi kata kerja frase: Jenis idiom ini selalu merupakan kombinasi kata kerja dan partikel (kata keterangan atau preposisi) misalnya, pergi, pasang, dan keluar.

2). Tournure idiom: Jenis idiom ini terdiri dari setidaknya tiga kata. Idi Tournure dibagi menjadi tujuh kategori berdasarkan strukturnya: a). Formulir yang berisi artikel wajib pasti atau tidak terbatas. Contohnya adalah dalam tubuh yang berarti "sekelompok orang". b). Bentuk yang mengandung binomial yang tidak dapat diubah. Contohnya adalah mondar-mandir yang berarti "bekerja berulang-ulang dengan rute pendek yang sama dengan gugup atau cemas". c). Objek langsung dan pengubah selanjutnya yang mungkin mengikuti kata kerja primer. Contohnya adalah tetap membuka mata yang berarti "waspada, perhatikan baik-baik atau waspada untuk sesuatu". d). Kata kerja utama tidak diikuti oleh objek langsung tetapi dengan preposisi plus kata benda atau tidak sama sekali. Contohnya adalah Ketakutan keluar dari akalnya yang berarti "menjadi sangat ketakutan". e). Kata kerja terdepan adalah. Contohnya adalah menaiki anak sungai yang berarti "berada dalam kesulitan besar, biasanya tanpa sarana membebaskan diri dari situ". f). Bentuknya mengandung wajib itu. Contohnya adalah menginjaknya yang 
berarti "cepatlah". g). Bentuknya berfungsi sebagai kata keterangan yang terdiri dari beberapa kata. Contohnya adalah tentu saja yang berarti "prosedur normal atau normal". 3). Binomial ireversibel: idiom jenis ini memiliki struktur tetap yang tidak dapat diubah. Biasanya terdiri dari dua kata yang dipisahkan oleh konjungsi, misalnya, ke sana kemari yang berarti "(gerakan) menuju dan menjauh dari sesuatu". 4). Ungkapan-ungkapan majemuk Phrasal: Jenis-jenis idiom ini mengacu pada suatu senyawa nominal yang terdiri dari preposisi / kata sifat plus kata benda, kata benda ditambah kata benda, dan kata kerja ditambah kata benda. Misalnya, kehilangan hati berarti "kehilangan keberanian atau rasa percaya diri seseorang”. 5). Menggabungkan idiom kata kerja: Menggabungkan idiom kata kerja biasanya dipisahkan oleh (-), dan memiliki beberapa bentuk seperti kata benda-kata kerja, dan kata sifat kata sifat. Ungkapan seperti ini banyak digunakan dalam istilah formal. Sebagai contoh, penggumpalan darah berarti "memenuhi Anda dengan kengerian". 6). Idiom semu: ini adalah "poleksonik leksem" satu atau lebih yang lekson konstituennya, terlepas dari kata-kata yang diizinkan secara morfotaksis, tidak secara simultan realisasi leksem independen di lingkungan lain juga, kecuali jika itu adalah lekson yang dilarang. " Contoh untuk kategori ini adalah chit-chat yang berarti "obrolan ringan".

Palmer F. R telah menyatakan tiga tipe umum. Mereka adalah: 1). Verba phrasal. Jenis idiom yang sangat umum dalam bahasa Inggris disebut "kata kerja Phrasal". Ini adalah kombinasi dari kata kerja plus kata keterangan. Beberapa contoh kata kerja phrasal idiomatik adalah menyerah, menyerah, pecah, rusak. 2). Kata kerja preposisional. Ini adalah urutan kata kerja, kata kerja dan kata depan, seperti go for yang artinya menyerang dan merawat yang berarti care. Contoh kata kerja, kata kerja, dan kata depan adalah up tahan dengan 'yang berarti mentolerir dan' hapus 'yang berarti membunuh. Kata-kata itu bukan idiom kolokasi yang tetap sehingga mereka tidak bisa berdiri sendiri, mereka perlu diikuti oleh kalimat lengkap. 3). Idiom Parsial. Sebuah idiom parsial adalah idiom di mana salah satu kata memiliki arti yang biasa; yang lain memiliki makna yang khusus untuk urutan tertentu, misalnya: rambut merah yang mengacu pada rambut, tetapi bukan rambut yang merah dalam istilah warna yang ketat. 
Lagu adalah seperangkat kata, puisi pendek, dll untuk dinyanyikan, biasanya dengan iringan musik. Lagu dapat dikatakan sebagai karya seni jika dibunyikan (dinyanyikan) dengan iringan alat musik. Sebuah lagu adalah komposisi musik yang berisi bagian vokal (lirik) yang dilakukan (dinyanyikan), biasanya disertai dengan alat musik (pengecualian akan menjadi lagu cappella).

Lirik adalah seperangkat kata yang membentuk sebuah lagu. Lirik dapat dipelajari dari perspektif akademis. Misalnya, beberapa lirik dapat dianggap sebagai bentuk komentar sosial. Lirik juga dapat dianalisis sehubungan dengan rasa persatuan (atau kurangnya persatuan) dengan musik

\section{METODE PENELITIAN}

Dalam melakukan penelitian ini, peneliti menggunakan metode deskriptif kualitatif karena data yang diambil dari kata slang dalam album Charlie Puth adalah dalam bentuk ekspresi idiomatik.

Menurut Fraenkel dan Wallen (1993), metode deskriptif kualitatif adalah metode yang digunakan untuk menjelaskan, menganalisis dan mengklasifikasikan sesuatu melalui berbagai teknik, survei, wawancara, kuesioner, observasi, dan teks.

Data adalah lagu-lagu dari album Charlie Puth berjudul "Nine Track Mind". Itu dirilis pada 2016. Ini terdiri dari empat belas lagu, mereka adalah: Satu panggilan, Berbahaya, Marvin gaye, Kehilangan pikiran saya, Kami tidak berbicara lagi, Injil saya, Sepanjang malam, Kiri kanan kiri, Lalu ada Anda, Menderita, Seperti Anda, Beberapa jenis cinta, Sampai jumpa lagi, Tidak ada masalah.

Dalam menganalisis lirik lagu, lirik berfungsi sebagai instrumen. Dalam studi ini, peneliti mengidentifikasi makna, jenis, dan berapa banyak ekspresi idiomatik yang ditemukan dalam album Nine Track Mind oleh Charlie Puth. Peneliti mengklasifikasikan jenis-jenis idiom oleh F.R Palmer (1976). Ini terdiri dari kata kerja phrasal, kata kerja preposisi, dan idiom parsial.

Dalam penelitian ini, penulis mengumpulkan data dengan melakukan langkahlangkah berikut, yang terdiri dari: 1). Mencari, peneliti mencari lirik dari situs resmi Charlie Puth yang dapat diakses di www.charlieputh.com. 2). Membaca, peneliti membaca lirik dan memahami seluruh konten terutama idiom. 3). 
Mengidentifikasi, saat membaca teks, peneliti mengidentifikasi idiom. Idiom yang diduga ditemukan dalam lirik digarisbawahi. Sebagai contoh: Anda jatuh.

\section{HASIL PEMBAHASAN DAN DISKUSI}

Data dianalisis berdasarkan langkah-langkah berikut: 1). Mengidentifikasi idiom lagu lirik Charlie Puth. Peneliti membaca lirik lagu baris demi baris dan ayat demi ayat dengan cermat untuk mengetahui frasa atau klausa yang merupakan idiom. 2). Menggambarkan, pada langkah ini peneliti menggambarkan makna idiom dengan menggunakan kamus, seperti kamus online Cambridge Advance Learning, kamus pembelajar Oxford, kamus gratis, kamus online McGraw hills, kamus online Merriam-Webster atau kamus online lainnya. 3). Tabulasi analisis idiom. Pada langkah ini, peneliti menempatkan idiom yang ditemukan dan interpretasi idiom dalam tabel, sehingga pembaca semakin mudah untuk memahami mereka. Tabelnya adalah sebagai berikut:

\section{Daftar ekspresi idiomatis}

\begin{tabular}{|l|l|l|l|l|}
\hline \multirow{2}{*}{ Idiom } & \multicolumn{2}{|c|}{ Jenis Idiom } & \multirow{2}{*}{ Makna } \\
\cline { 2 - 4 } & $\begin{array}{l}\text { Phrasal Verb } \\
\text { (V+Adv) }\end{array}$ & $\begin{array}{l}\text { Preposition Verb } \\
\text { (V+Prep) }\end{array}$ & $\begin{array}{l}\text { Partial } \\
\text { Idiom } \\
\text { (V+N) }\end{array}$ & \\
\hline & & & & \\
\hline
\end{tabular}

4). Setelah peneliti mengidentifikasi dan mengklasifikasikan jenis ekspresi idiomatik, data dihitung untuk mengetahui frekuensi dan persentase. Formula berikut diterapkan:

Persentase $=(f x: x) \times 100$

Catatan: $f x=$ total ekspresi idiomatik

$x=$ skor total semua ekspresi idiomatik

5). Akhirnya, data disajikan dalam bentuk tabel sebagai berikut:

\section{Frekuensi dan jenis persentase ekspresi idiomatik}

\begin{tabular}{|c|l|c|c|}
\hline No & \multicolumn{1}{|c|}{ Jenis Idiom } & Frekuensi & $\begin{array}{c}\text { Persentase } \\
(\%)\end{array}$ \\
\hline 1 & Phrasal Verb & & \\
\hline 2 & Prepositional Verb & & \\
\hline
\end{tabular}




\begin{tabular}{|l|l|l|l|}
\hline 3 & Partial Idiom & & \\
\hline & Total & & \\
& & & \\
\hline
\end{tabular}

\section{KESIMPULAN}

Ekspresi idiomatik digunakan dalam komunikasi formal dan informal. Dalam Linguistik, idiom didefinisikan sebagai ekspresi tetap yang biasanya digunakan dalam arti kiasan dan mereka memiliki makna sewenang-wenang. Idiom adalah sekelompok kata yang disusun dalam urutan tetap yang memiliki makna tertentu di mana ia berbeda dari makna setiap kata sendiri tidak dapat diterjemahkan dengan benar secara harfiah. Penelitian ini adalah untuk mengetahui jenis, dan makna serta untuk mengetahui nomornya. ekspresi idiomatik dalam lirik album Charlie Puth Nine Track Mind yang berisi empat belas judul lagu. Mereka adalah: satu panggilan, berbahaya, marvin gaye, kehilangan akal, kita tidak berbicara lagi, Injil saya, sepanjang malam, lalu ada Anda, kiri kanan kiri, menderita, seperti Anda, beberapa jenis cinta,

sampai jumpa lagi, dan hanya masalah. Peneliti menggunakan tiga jenis idiom berdasarkan teori Palmers, mereka adalah kata kerja phrasal, idiom parsial dan kata kerja preposisi. Total numbe adalah 80 ekspresi idiomatik, yang terdiri dari 19 ekspresi idiomatik dalam pola kata kerja phrasal, 25 ekspresi idiomatik dalam pola idiom parsial, dan 36 ekspresi idiomatik dalam pola kata kerja preposisional. Jadi ekspresi idiomatik yang paling banyak digunakan dalam lirik album Charlie Puth Nine Track Mind adalah kata kerja preposisional, misalnya: pergi keluar, lari ke, mencari, mencari, dll.

\section{Saran}

Berdasarkan kesimpulan itu, disarankan bahwa: Frist, untuk mahasiswa Jurusan Bahasa Inggris, memang perlu untuk mempelajari dan memahami idiom itu sendiri agar memiliki cara komunikasi yang baik apakah itu diucapkan atau ditulis. Selain itu, sebagai siswa yang belajar bahasa Inggris, mempelajari idiom bahasa Inggris dapat menghindari orang asing dari miskomunikasi dalam percakapan bahasa Inggris, namun hal itu dapat memperkaya kosakata dan pengetahuan siswa tentang budaya bahasa Inggris. Kedua, untuk para dosen 
Jurusan Bahasa Inggris, ekspresi idiomatik harus diajarkan lebih dalam baik dalam berbicara, menulis, atau subjek terjemahan, karena meningkatkan keterampilan mereka menjadi seperti orang asli, untuk memperkenalkan keberadaan idiom dan fungsinya, dan tentu saja untuk memperkaya kosa kata mereka, terutama tentang ekspresi idiomatik. Terakhir, untuk peneliti lain. Penelitian ini dapat menyarankan peneliti berikutnya untuk melakukan penelitian lebih lanjut yang dapat meningkatkan penelitian ini karena penelitian ini sebenarnya dapat diperluas dan diperluas ke subjek lain dan juga dalam pengaturan yang berbeda.

\section{DAFTAR PUSTAKA}

Adam, Makkai. (1972). Idiom Structure in English. Paris: The Hague.

Antara, Putu Widi. (2015). The Types of Idiom and Their Meaning in Maroon 5's Hands All Over Album, (Udayana University, 2015). Journal of Arts and Humanities.

Brown, H. D. (2000). Teaching by Principles. California: Longman press.

Dixon, Robert J. (2004). Essential Idiomsin English. USA: Regents Publishing Company. Inc

F.R, Palmer. (1976). SEMANTIC A New Outline. Cambridge: University Press.

Frankel, J. \& Wallen, N. (1993). How to Design and Evaluate research in Education, (second edition). New York: McGraw-Hill Inc.

Gay, L. J. (1987). Educational Research: Competences Analysis and Application.

Hurford, J.M and Heasley,B.1995. Semantic: a Course book. Cambridge: Cambridge University.

Jacqueline Ambrose. (2020). Why Idioms Are Important For English Language Learners.

Joodi, A.M. (2012). A Study of The Problems of Learning and Translating Idioms. Journal of College of Education for Women. 3(4). 
Kurniawati, Hafidah. (2007). An Analysis on English Idiomatic Expressions Translated into Indonesian in "A Stranger in the Mirror, (Sebelas Maret University: 2007)

Langlotz, Andreas. 2006. Occasional Adnominal Idiom Modification-A Cognitive Linguistic Approach. International Journal of English Studies, vol. 6 . ISSN: 2157-4898.

Lim, Tan cheng. (2004). Advance English Idioms for Effective communication. Jakarta: Penerbit Erlangga.

Mantyla, K. (2004). Idioms and Language Users: the Effect of the Characteristics of Idioms on Their Recognition and Interpretation by Native and NonNative Speakers of English, University of Jyväskylä Press, 2004.

McCarthy, M and O'Dell, F. (2003). English Idioms in Use. UK: Cambridge University Press.

Moon, R. (1998). Fixed Expressions and Idioms in English: A Corpus-Based Approach.

Purnamasari, A. V, (2009). Teaching English Idioms to EFL Students through Songs. Jurnal Pengembangan Pendidikan. 6(2).

Puspitasari Atika and Saputra Efdy. (2011). A Journal entitled Idiomatic Expressions Used in Westlife's Songs. Jurnal Ilmiah Bina Bahasa. 4(2).

Wiradharma, P. R. (2013). The Analysis of Idioms and Comparison in Adele's and Mariah Carey's Song lyrics, Udayana University: Portal Garuda. 